\title{
DISTRIBUTION OF SOME RADIONUCLIDES IN CORN AND SOIL FROM DIFFERENT LOCATIONS IN THE SURROUNDING OF SKOPJE
}

\author{
Aleksandra Angjeleska ${ }^{1^{*}}$, Elizabeta Dimitrieska-Stojković ${ }^{1}$, Radmila Črčeva-Nikolovska ${ }^{1}$, \\ Zehra Hajrulai-Musliu1, Biljana Stojanovska-Dimzoska1 ${ }^{1}$, Slobodan Bogoevski², Boško Boškovski ${ }^{2}$ \\ ${ }^{l}$ Faculty of Veterinary Medicine, Food Institute, “Ss. Cyril and Methodius” University in Skopje, \\ Lazar Pop Trajkov, 5, MK-1000 Skopje, Republic of North Macedonia \\ ${ }^{2}$ Faculty of Technology and Metallurgy, "Ss. Cyril and Methodius" University in Skopje, \\ Ruđer Bosković 16, MK-1000 Skopje, Republic of North Macedonia \\ mizazandra@fvm.ukim.edu.mk
}

\begin{abstract}
A b s t r a c t: Concentration of natural radionuclides in soil and plants are crucial parameters for defining the level of contamination of the environment. The samples for analysis were collected from the 14 localities of the surrounding of Skopje, of cultivated and uncultivated soil. The specific activity of radionuclides ${ }^{232} \mathrm{Th},{ }^{226} \mathrm{Ra}$ and ${ }^{40} \mathrm{~K}$ are determined by gamma spectrometry. The analysis results show that the mean value of ${ }^{232} \mathrm{Th}$ specific activity in cultivated soil was $43.74 \pm 4.99 \mathrm{~Bq} \cdot \mathrm{kg}^{-1}$, while in uncultivated soil it was $35.70 \pm 5.65 \mathrm{~Bq} \cdot \mathrm{kg}^{-1}$. The ${ }^{226} \mathrm{Ra}$ specific activity had a mean value of $34.09 \pm 6.53 \mathrm{~Bq} \cdot \mathrm{kg}^{-1}$ and $28.30 \pm 5.54 \mathrm{~Bq} \cdot \mathrm{kg}^{-1}$ in cultivated and uncultivated soil, respectively. The specific activity of ${ }^{40} \mathrm{~K}$ from all localities was higher than the one of ${ }^{232} \mathrm{Th}$ and ${ }^{226} \mathrm{Ra}$, and in cultivated soil the mean value was $608.12 \pm 70.43 \mathrm{~Bq} \cdot \mathrm{kg}^{-1}$, while in uncultivated soil it was $506.54 \pm 59.96 \mathrm{~Bq} \cdot \mathrm{kg}^{-1}$. From the same locations corn samples were also collected for analysis. Concentration of natural radionuclides in corn is lower then referent values. From the results ttransfer factor (TF) of natural radionuclides from soil to corn was calculated.
\end{abstract}

Key words: soil; corn; radionuclides; gamma spectrometry; transfer factor

\section{ДИСТРИБУЦИЈА НА РАДИОНУКЛИДИ ВО ПЧЕНКА И ЗА ПОЧВА ОД РАЗЛИЧНИ ЛОКАЛИТЕТИ ОД ОКОЛИНАТА НА СКОПЈЕ}

\begin{abstract}
А п с т р а к т: Концентрацијата на природните радионуклиди во почвата и растенијата се основни параметри за дефинирање на степенот на контаминацијата на животната средина, како и на радијациониот ризик за населението. Примероци за анализа се земени од 14 локалитети од околината на Скопје, од обработлива и необработлива почва. Специфичната активност на радионуклидите ${ }^{232} \mathrm{Th},{ }^{226} \mathrm{Ra}$ и ${ }^{40} \mathrm{~K}$ e определена со гама-спектрометрија. Средната вредност на специфичната активност на ${ }^{232} \mathrm{Th}$ во обработлива почва изнесува $43.74 \pm 4.99 \mathrm{~Bq} \cdot \mathrm{kg}^{-1}$, а во необработлива почва $35.70 \pm 5.65 \mathrm{~Bq} \cdot \mathrm{kg}^{-1}$. Специфичната активност на ${ }^{226} \mathrm{Ra}$ има средна вредност од $34.09 \pm 6.53 \mathrm{~Bq} \cdot \mathrm{kg}^{-1}$ и $28.30 \pm 5.54 \mathrm{~Bq} \cdot \mathrm{kg}^{-1}$ за обработлива и необработлива почва соодветно. Специфичната активност на ${ }^{40} \mathrm{~K}$ на сите локалитети е повисока во однос на ${ }^{232} \mathrm{Th}$ и ${ }^{226} \mathrm{Ra}$, и $3 \mathrm{a}$ обработливата почва средната вредност изнесува $608.12 \pm 70.43 \mathrm{~Bq} \cdot \mathrm{kg}^{-1}$, а за необработливата почва изнесува $506.54 \pm 59.96 \mathrm{~Bq} \cdot \mathrm{kg}^{-1}$. Од истите места се земени и примероци од пченка за анализа. Концентрацијата на радионуклидите во пченката е пониска во однос на референтните вредности. Од добиените резултати е пресметан и факторот на тренсфер (ТФ) на природните радионуклиди од почвата во пченката.
\end{abstract}

Клучни зборови: почва; пченка; радионуклиди; гама-спектрометрија; радијационен ризик

\section{INTRODUCTION}

Dominantly radionuclides are accumulated in the soil surface. Migration of the radionuclides in the soil depends on various factors, dominantly by the soil properties, concentration of stable isotopes, as well as the intensity of the agricultural activity [1-3].

The aim of this research is to define concentration of natural radionuclides in soil $[4,5]$. The specific activity of ${ }^{226} \mathrm{Ra},{ }^{232} \mathrm{Th}$ and ${ }^{40} \mathrm{~K}$ is determined 
on samples collected from cultivated and uncultivated soil [6-9].

Radionuclides in soil are available for the plants [13-24]. Also the corn extracting the radionuclides from soil. Corn is used as food in the human diet and also as animal feed. Consumption of contaminated corn may cause serious health disorders. Therefore the concentration of natural radionuclides in corn is determined. Also the transfer factors of radionuclides from soil to corn are defined $[25,26]$.

\section{MATERIALS AND METHODS}

The research area is the surrounding of Skopje. The total area is $2100 \mathrm{~km}^{2}$ with an altitude between 173 and $340 \mathrm{~m}$. The average annual air temperature was $13.7^{\circ} \mathrm{C}$, with average annual rainfalls of 412.7 $\mathrm{mm}[27]$.

The soil samples for analysis were collected in 2014 from 14 localities in the surrounding of Skopje (Figure 1). The samples were collected from cultivated and uncultivated soil, by appropriate soil sampling tube at three various depths: $0-5 \mathrm{~cm}, 5-10$ $\mathrm{cm}$ and $10-15 \mathrm{~cm}$. The soil samples were collected in duplicates, six soil samples from each locality. During the sampling, a special care was taken for the micro-location flatness, in order to exclude the possibility for horizontal radionuclide translocation.

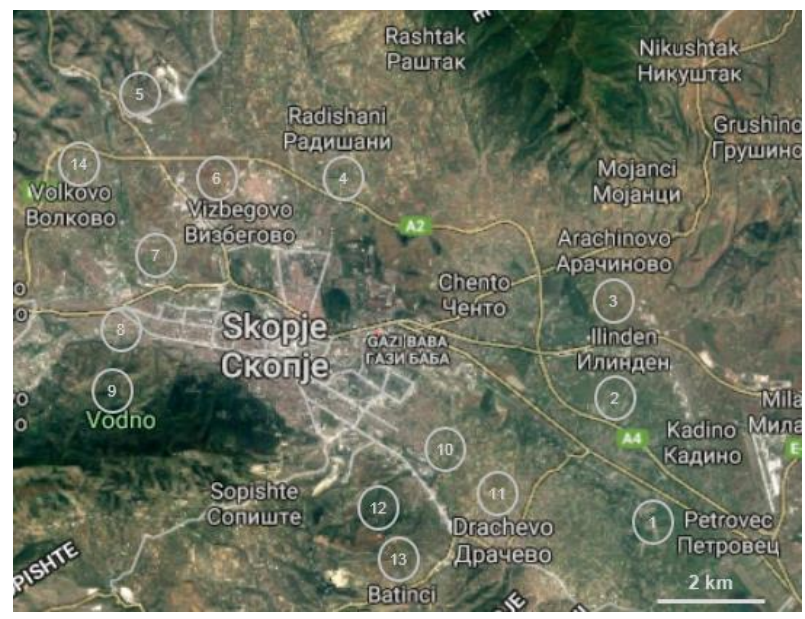

Fig. 1. Sampling localities of soil from the surrounding of City of Skopje: 1 - Petrovec, 2 - Ilinden, 3 - Aračinovo, 4 - Radišani, 5 - Chucher Sandevo, 6 - Vizbegovo,

7 - Bardovci, 8 - Saraj, 9 - Nerezi, 10 - Lisiče,

11 - Dračevo, 12 - Pintija, 13 - Batinci, 14 - Volkovo

After removing the stones and organic impurities, the samples were dried in an oven at $110^{\circ} \mathrm{C}$ for
24 hours, to remove the moisture. Then, the samples were crushed and passed through $150 \mu \mathrm{m}$ sieve. A mass from 480 to $490 \mathrm{~g}$ of each homogenized sample was weighed and packed in polyethylene Marinelli containers. After tightening, the containers were sealed with adhesive tape and left for 21 days before measuring with gamma spectrometry. This was in order to ensure that the daughter products of ${ }^{226} \mathrm{Ra}$ and ${ }^{228} \mathrm{Th}$ have achieved equilibrium with the respective parent radionuclides.

The gamma spectrometry was used for determination of radioactivity of the soil samples [28, 29]. The spectrometer consisted of an HPGe detector, model 3020 (Canberra Packard, Meriden, CT, USA), with active volume of $180 \mathrm{~cm}^{3}$, relative efficiency of $30 \%$, operating voltage $3000 \mathrm{~V}$, and resolution of $2 \mathrm{keV}$ at $1332.5 \mathrm{keV}$. Data acquisition and analysis were performed with 8192 channel digital analyzer; duration of acquisition interval for each sample was $65000 \mathrm{~s}$. The activity of ${ }^{226} \mathrm{Ra}$ was determined from the gamma lines associated with low half-live time daughters of ${ }^{214} \mathrm{Bi}(609.31$, 1120.29 and $1794.49 \mathrm{keV})$ and ${ }^{214} \mathrm{~Pb}(351.93 \mathrm{keV})$. The ${ }^{232} \mathrm{Th}$ activity was determined by $338.4,911.2$ and $969.1 \mathrm{keV}$ gamma lines form ${ }^{227} \mathrm{Ac}$ and its decay products. The gamma line at $1460.8 \mathrm{keV}$ was used to determine the activity of ${ }^{40} \mathrm{~K}$.

Efficiency calibration was performed with mixed calibration standard sources MBSS2, supplied from the Czech Metrological Institute, Inspectorate for Ionizing Radiation. In order to determine the background distribution in the detector environment, empty sealed Marinelli beaker with the same geometry was measured at equal counts as the soil samples. The analysis procedure included the subtraction of the background spectrum.

The specific activity (A) is determined according the equation [12]:

$$
A=\frac{\frac{N}{t}-\frac{N_{0}}{t_{0}}}{\varepsilon \cdot \gamma \cdot m}\left(\mathrm{~Bq} \cdot \mathrm{kg}^{-1}\right)
$$

where $N$ is clean surface of peak accumulated from a specific radionuclide in analysis of a specific sample (number of readings), $N_{0}$ is clean surface of peak accumulated from the spot of a specific radionuclide without an analysis of sample (number of readings), $t$ is live time of accumulation of the sample spectrum (s), $t_{0}$ is live time of accumulation of the phone spectrum (s), $\varepsilon$ is detector efficiency for a given energy (for a specific peak), $\gamma$ is intensity of gamma transition in radioactive decay for a respective radionuclide (\%), and $m$ is sample mass ( $\mathrm{kg}$ ). 
Corn samples were analyzed from the same locations, 3 samples from each location, which is in accordance with the International Atomic Energy Agency recommendations.

Transfer of radionuclides from soil to plant is determined by transfer factor - TF [25. 26]. This factor include radionuclide concentration per gram of plant (dry or wet plant weight) $\left(\mathrm{Bq} \cdot \mathrm{kg}^{-1}\right)$ at harvest divided by radionuclide concentration per gram of soil $\left(\mathrm{Bq} \cdot \mathrm{kg}^{-1}\right)$. TF is dependent on the factors such as: radionuclide type, product type, soil type, $\mathrm{EC}, \mathrm{pH}$ and bicarbonate content of the soil. Using TF we can find if plants receive contamination from soil or root.

$$
\mathrm{TF}=\frac{\begin{array}{c}
\text { radionuclide concentration } \\
\text { in plant (dry weight) }
\end{array}}{\begin{array}{c}
\text { radionuclide concentration } \\
\text { in soil (dry weight) }
\end{array}}
$$

\section{RESULTS AND DISCUSSION}

In Tables 1, 2 and 3 the specific activities of radionuclides of ${ }^{226} \mathrm{Ra},{ }^{232} \mathrm{Th}$ and ${ }^{40} \mathrm{~K}$ are presented for uncultivated and cultivated soil samples. The obtained results are from six measurements at three various soil depths (in duplicate). The values are associated with the respective standard deviations (SD).

Table 1

Comparison results from measured specific activities $(A)$ of ${ }^{226} \mathrm{Ra}$

\begin{tabular}{lccc}
\hline \hline \multirow{2}{*}{ Sampling sites } & \multicolumn{2}{c}{ A $\pm \mathrm{SD}\left(\mathrm{Bq} \cdot \mathrm{kg}^{-1}\right)$} & Increased \\
\cline { 2 - 4 } & Uncultivated soil & Cultivated soil & $\mathrm{A} \%$ \\
\hline Petrovec & $28.22 \pm 1.51$ & $34.36 \pm 4.19$ & 21.76 \\
Ilinden & $26.01 \pm 1.53$ & $32.41 \pm 3.25$ & 24.61 \\
Aračinovo & $33.79 \pm 1.82$ & $41.21 \pm 1.75$ & 21.96 \\
Radišani & $27.32 \pm 4.20$ & $31.39 \pm 1.18$ & 14.90 \\
Čučer-Sandevo & $23.86 \pm 1.31$ & $24.06 \pm 0.56$ & 0.83 \\
Vizbegovo & $36.95 \pm 2.55$ & $40.78 \pm 1.02$ & 10.37 \\
Bardovci & $39.43 \pm 4.16$ & $41.91 \pm 5.61$ & 6.30 \\
Saraj & $32.32 \pm 4.52$ & $36.03 \pm 0.54$ & 11.48 \\
Nerezi & $27.62 \pm 1.52$ & $36.33 \pm 1.32$ & 31.54 \\
Lisiče & $20.38 \pm 1.40$ & $26.27 \pm 1.37$ & 28.90 \\
Dračevo & $22.64 \pm 2.05$ & $25.73 \pm 1.64$ & 13.65 \\
Pintija & $30.69 \pm 1.42$ & $40.87 \pm 1.23$ & 33.17 \\
Batinci & $27.12 \pm 1.32$ & $36.01 \pm 4.21$ & 32.78 \\
Volkovo & $23.70 \pm 1.51$ & $29.30 \pm 5.14$ & 23.63 \\
\hline \hline
\end{tabular}

Table 2

Comparison results from measured specific activities (A) of ${ }^{232} \mathrm{Th}$

\begin{tabular}{lccc}
\hline \hline \multirow{2}{*}{ Sampling sites } & \multicolumn{2}{c}{$\mathrm{A} \pm \mathrm{SD}\left(\mathrm{Bq} \cdot \mathrm{kg}^{-1}\right)$} & Increased \\
\cline { 2 - 4 } & Uncultivated soil & Cultivated soil & $\mathrm{A} \%$ \\
\hline Petrovec & $28.27 \pm 2.44$ & $42.42 \pm 4.23$ & 50.05 \\
Ilinden & $32.71 \pm 1.22$ & $42.45 \pm 1.18$ & 29.78 \\
Aračinovo & $45.67 \pm 4.44$ & $48.08 \pm 1.16$ & 5.27 \\
Radišani & $39.61 \pm 1.21$ & $51.47 \pm 2.67$ & 29.94 \\
Čučer-Sandevo & $33.90 \pm 3.40$ & $38.54 \pm 2.50$ & 13.69 \\
Vizbegovo & $38.12 \pm 2.52$ & $49.57 \pm 1.67$ & 30.04 \\
Bardovci & $42.92 \pm 4.50$ & $49.82 \pm 2.21$ & 16.08 \\
Saraj & $40.32 \pm 2.25$ & $40.96 \pm 1.91$ & 1.59 \\
Nerezi & $38.40 \pm 2.02$ & $52.19 \pm 1.63$ & 35.91 \\
Lisiče & $34.73 \pm 2.27$ & $40.80 \pm 2.05$ & 17.48 \\
Dračevo & $28.57 \pm 4.35$ & $39.87 \pm 1.47$ & 39.55 \\
Pintija & $33.57 \pm 1.91$ & $45.96 \pm 3.30$ & 36.91 \\
Batinci & $35.97 \pm 2.30$ & $42.35 \pm 1.21$ & 17.74 \\
Volkovo & $27.07 \pm 2.32$ & $41.90 \pm 3.63$ & 54.78 \\
\hline \hline
\end{tabular}

T a ble 3

Comparison results from measured specific activities (A) of ${ }^{40} \mathrm{~K}$

\begin{tabular}{lccc}
\hline \hline \multirow{2}{*}{ Sampling sites } & \multicolumn{2}{c}{$\mathrm{A} \pm \mathrm{SD}\left(\mathrm{Bq} \cdot \mathrm{kg}^{-1}\right)$} & Increased \\
\cline { 2 - 4 } & Uncultivated soil & Cultivated soil & $\mathrm{A} \%$ \\
\hline Petrovec & $439.94 \pm 20.12$ & $587.59 \pm 11.20$ & 33.56 \\
Ilinden & $489.63 \pm 20.84$ & $573.65 \pm 16.41$ & 17.16 \\
Aračinovo & $540.24 \pm 19.69$ & $676.71 \pm 18.18$ & 25.26 \\
Radišani & $507.19 \pm 20.30$ & $622.56 \pm 9.09$ & 22.75 \\
Čučer-Sandevo & $450.80 \pm 21.46$ & $501.86 \pm 55.10$ & 11.33 \\
Vizbegovo & $605.29 \pm 44.91$ & $704.54 \pm 16.95$ & 16.40 \\
Bardovci & $625.81 \pm 48.21$ & $706.86 \pm 13.63$ & 12.95 \\
Saraj & $476.45 \pm 22.09$ & $628.70 \pm 19.16$ & 31.96 \\
Nerezi & $522.71 \pm 20.12$ & $623.47 \pm 16.19$ & 19.28 \\
Lisiče & $437.26 \pm 45.55$ & $526.76 \pm 38.58$ & 20.47 \\
Dračevo & $431.45 \pm 21.25$ & $549.21 \pm 24.17$ & 27.29 \\
Pintija & $522.60 \pm 21.74$ & $655.97 \pm 25.56$ & 25.52 \\
Batinci & $488.56 \pm 20.09$ & $629.50 \pm 31.58$ & 28.85 \\
Volkovo & $476.07 \pm 20.09$ & $526.27 \pm 72.05$ & 10.54 \\
\hline \hline
\end{tabular}


The variations in the specific activity values of radionuclides of ${ }^{226} \mathrm{Ra},{ }^{232} \mathrm{Th}$ and ${ }^{40} \mathrm{~K}$ are due to the various physical and geochemical soil properties. As expected, and in accordance with the worldwide data $[30,31]$, the specific activities of ${ }^{232} \mathrm{Th}$ are higher than the ones of ${ }^{226} \mathrm{Ra}$, while the values of the specific activities of ${ }^{40} \mathrm{~K}$ are one magnitude higher.

The statistical parameters are calculated and presented in Table 4.

Table 4

Statistical data analysis of ${ }^{226} \mathrm{Ra},{ }^{232} \mathrm{Th}$ and ${ }^{40} \mathrm{~K}$

\begin{tabular}{|c|c|c|c|c|c|c|}
\hline & \multicolumn{2}{|c|}{${ }^{226} \mathrm{Ra}$} & \multicolumn{2}{|c|}{${ }^{232} \mathrm{Th}$} & \multicolumn{2}{|c|}{${ }^{40} \mathrm{~K}$} \\
\hline & $\begin{array}{l}\text { Uncultivated } \\
\text { soil }\end{array}$ & $\begin{array}{l}\text { Cultivated } \\
\text { soil }\end{array}$ & $\begin{array}{l}\text { Uncultivated } \\
\text { soil }\end{array}$ & $\begin{array}{l}\text { Cultivated } \\
\text { soil }\end{array}$ & $\begin{array}{l}\text { Uncultivated } \\
\text { soil }\end{array}$ & $\begin{array}{c}\text { Cultivated } \\
\text { soil }\end{array}$ \\
\hline Mean value $\left(\mathrm{Bq} \cdot \mathrm{kg}^{-1}\right)$ & 28.58 & 34.05 & 35.70 & 44.74 & 501.00 & 608.12 \\
\hline Median $\left(\mathrm{Bq} \cdot \mathrm{kg}^{-1}\right)$ & 27.47 & 35.19 & 35.35 & 42.44 & 489.10 & 623.02 \\
\hline $\operatorname{Minimum}\left(\mathrm{Bq} \cdot \mathrm{kg}^{-1}\right)$ & 20.38 & 24.06 & 27.07 & 38.54 & 431.45 & 501.86 \\
\hline $\operatorname{Maximum}\left(\mathrm{Bq} \cdot \mathrm{kg}^{-1}\right)$ & 39.43 & 41.91 & 45.67 & 52.19 & 625.81 & 706.86 \\
\hline $\mathrm{SD}\left(\mathrm{Bq} \cdot \mathrm{kg}^{-1}\right)$ & 5.49 & 6.53 & 5.61 & 4.99 & 61.80 & 70.43 \\
\hline Range (max-min) & 19.05 & 17.85 & 18.60 & 13.65 & 194.36 & 205.00 \\
\hline Skewness & 0.58 & -0.27 & 0.05 & 0.42 & 0.94 & -0.07 \\
\hline Kurtosis & -0.28 & -1.17 & -0.65 & -1.42 & 0.38 & -1.05 \\
\hline
\end{tabular}

For cultivated soils, the mean value of the specific activities of ${ }^{226} \mathrm{Ra}$ is lower than the worldwide average value $\left(35 \mathrm{~Bq} \cdot \mathrm{kg}^{-1}\right)$. The calculated mean value of ${ }^{232} \mathrm{Th}$ is higher than the world average value $\left(30 \mathrm{~Bq} \cdot \mathrm{kg}^{-1}\right)$. Also the calculated mean value of the specific activities of ${ }^{40} \mathrm{~K}$ is higher than the worldwide average value $\left(400 \mathrm{~Bq} \cdot \mathrm{kg}^{-1}\right)$ [30, 31]. According to presented results for uncultivated soil, the mean values of the specific activities of ${ }^{226} \mathrm{Ra}$ is lower than the world average value. The calculated mean values of the specific activities of ${ }^{232} \mathrm{Th}$ and ${ }^{40} \mathrm{~K}$ are higher than the world average values [30, 31].

There are significant variations between the two data series of activities measured for uncultivated and cultivated soil samples. The specific activity values of radionuclides of ${ }^{226} \mathrm{Ra},{ }^{232} \mathrm{Th}$ and ${ }^{40} \mathrm{~K}$ are higher in cultivated soil as a consequence of fertilization by agricultural activity [10-12]. The main source for the increased levels of natural radionuclides are phosphate and potassium fertilizers. According to literature data, the levels of ${ }^{226} \mathrm{Ra},{ }^{232} \mathrm{Th}$ and ${ }^{40} \mathrm{~K}$ in fertilizers may vary up to $1852 \mathrm{~Bq} \cdot \mathrm{kg}^{-1}$, $65 \mathrm{~Bq} \cdot \mathrm{kg}^{-1}$ and $4860 \mathrm{~Bq} \cdot \mathrm{kg}^{-1}$. Also the statistical values are calculated (Table 5).

Plants don't have equal affinity for extraction of present radionuclides in soils. The specific activ- ities (A) values of ${ }^{226} \mathrm{Ra},{ }^{232} \mathrm{Th}$ and ${ }^{40} \mathrm{~K}$ in corn samples are presented in Table 6 . The specific activity value of radionuclide of ${ }^{40} \mathrm{~K}$ is the highest, because $\mathrm{K}$ is a major nutrient for plants.

The transfer factor soil to corn is also calculated (Table 7). The transfer factor values of ${ }^{226} \mathrm{Ra}$ are higher than the ${ }^{232} \mathrm{Th}$, as a consequence of difference in solubility. Because $\mathrm{K}$ is a major nutrient, ${ }^{40} \mathrm{~K}$ has the highest values for soil-to-corn TF in comparison with radionuclides of ${ }^{226} \mathrm{Ra}$ and ${ }^{232} \mathrm{Th}[25,26]$.

Table 5

\begin{tabular}{lccc}
\multicolumn{4}{c}{ Calculated statistical increasing } \\
\hline \hline & ${ }^{226} \mathrm{Ra}$ & ${ }^{232} \mathrm{Th}$ & ${ }^{40} \mathrm{~K}$ \\
\hline Mean value $\left(\mathrm{Bq} \cdot \mathrm{kg}^{-1}\right)$ & 19.71 & 27.06 & 21.67 \\
Median $\left(\mathrm{Bq} \cdot \mathrm{kg}^{-1}\right)$ & 21.86 & 29.86 & 21.61 \\
Minimum $\left(\mathrm{Bq} \cdot \mathrm{kg}^{-1}\right)$ & 0.83 & 1.59 & 10.54 \\
Maximum $\left(\mathrm{Bq} \cdot \mathrm{kg}^{-1}\right)$ & 33.17 & 54.78 & 33.56 \\
$\mathrm{SD}\left(\mathrm{Bq} \cdot \mathrm{kg}^{-1}\right)$ & 10.29 & 15.82 & 7.45 \\
Range $(\mathrm{max}-\mathrm{min})$ & 32.34 & 53.19 & 23.02 \\
Skewness & -0.29 & 0.11 & 0.01 \\
Kurtosis & -0.97 & -0.68 & -1.10 \\
\hline \hline
\end{tabular}


T a ble 6

\begin{tabular}{lccc}
\multicolumn{4}{c}{ Specific activities $(A)$ of ${ }^{226} \mathrm{Ra}^{232}{ }^{23}$ Th and ${ }^{40} \mathrm{~K}$} \\
for corn samples \\
\hline Sampling sites & \multicolumn{3}{c}{$\mathrm{A} \pm \mathrm{SD}\left(\mathrm{Bq} \cdot \mathrm{kg}^{-1}\right)$} \\
\cline { 2 - 4 } & ${ }^{226} \mathrm{Ra}$ & ${ }^{223} \mathrm{Th}$ & ${ }^{40} \mathrm{~K}$ \\
\hline Petrovec & $0.04 \pm 0.10$ & $0.06 \pm 0.02$ & $108.15 \pm 2.00$ \\
Ilinden & $1.30 \pm 0.40$ & & $99.00 \pm 2.00$ \\
Aračinovo & $0.16 \pm 0.04$ & $0.02 \pm 0.12$ & $69.30 \pm 1.00$ \\
Radišani & $0.73 \pm 0.42$ & $0.08 \pm 0.03$ & $85.35 \pm 1.50$ \\
Čučer-Sandevo & $0.17 \pm 0.11$ & & $99.86 \pm 1.54$ \\
Vizbegovo & $0.40 \pm 0.05$ & $0.17 \pm 0.20$ & $115.54 \pm 2.40$ \\
Bardovci & $0.08 \pm 0.03$ & & $115.26 \pm 2.00$ \\
Saraj & $0.29 \pm 0.20$ & $0.15 \pm 0.03$ & $92.00 \pm 1.70$ \\
Nerezi & $0.38 \pm 0.20$ & $0.10 \pm 0.40$ & $89.57 \pm 1.50$ \\
Lisiče & $0.61 \pm 0.21$ & $1.02 \pm 0.45$ & $117.21 \pm 2.50$ \\
Dračevo & $0.48 \pm 0.20$ & $0.30 \pm 0.25$ & $78.02 \pm 2.00$ \\
Pintija & $0.61 \pm 0.25$ & $0.11 \pm 0.20$ & $195.97 \pm 2.00$ \\
Batinci & $0.33 \pm 0.15$ & $0.17 \pm 0.05$ & $107.50 \pm 2.35$ \\
Volkovo & $0.62 \pm 0.08$ & $0.94 \pm 0.04$ & $112.48 \pm 2.50$ \\
\hline \hline
\end{tabular}

T a b le 7

Transfer factor (TF) soil to corn

\begin{tabular}{lccc}
\hline \hline Sampling sites & ${ }^{226} \mathrm{Ra}$ & ${ }^{223} \mathrm{Th}$ & ${ }^{40} \mathrm{~K}$ \\
\hline Petrovec & 0.011 & 0.001 & 0.184 \\
Ilinden & 0.040 & $<\mathrm{MDA}$ & 0.172 \\
Aračinovo & 0.003 & 0.001 & 0.102 \\
Radišani & 0.023 & 0.001 & 0.137 \\
Čučer-Sandevo & 0.007 & $<\mathrm{MDA}$ & 0.198 \\
Vizbegovo & 0.009 & 0.003 & 0.163 \\
Bardovci & 0.001 & $<\mathrm{MDA}$ & 0.163 \\
Saraj & 0.008 & 0.003 & 0.146 \\
Nerezi & 0.010 & 0.001 & 0.143 \\
Lisiče & 0.023 & 0.025 & 0.222 \\
Dračevo & 0.018 & 0.007 & 0.142 \\
Pintija & 0.014 & 0.002 & 0.298 \\
Batinci & 0.009 & 0.004 & 0.170 \\
Volkovo & 0.021 & 0.022 & 0.213 \\
\hline \hline
\end{tabular}

\section{CONCLUSIONS}

The gamma spectrometry was used to determine the concentration of natural radionuclides ${ }^{226} \mathrm{Ra}$,
${ }^{232} \mathrm{Th}$ and ${ }^{40} \mathrm{~K}$ in soil from 14 localities of the surrounding of Skopje. The results show that the mean value of specific activity of ${ }^{232} \mathrm{Th}$ is $44.74 \mathrm{~Bq} \cdot \mathrm{kg}^{-1}$ in cultivated soil, while in uncultivated soil is 35.70 $\mathrm{Bq} \cdot \mathrm{kg}^{-1}$. The ${ }^{226} \mathrm{Ra}$ specific activity has a mean value of $34.05 \mathrm{~Bq} \cdot \mathrm{kg}^{-1}$ and $28.58 \mathrm{~Bq} \cdot \mathrm{kg}^{-1}$ in cultivated and uncultivated soil, respectively. The specific activity of ${ }^{40} \mathrm{~K}$ from all localities was higher than the ones of ${ }^{232} \mathrm{Th}$ and ${ }^{226} \mathrm{Ra}$, and in cultivated soil the mean value is $608.12 \mathrm{~Bq} \cdot \mathrm{kg}^{-1}$, while in uncultivated soil it is $501.00 \mathrm{~Bq} \cdot \mathrm{kg}^{-1}$.

The obtained data indicate that the specific activity of natural radionuclides in uncultivated soil is significantly lower than in cultivated soil. This is a consequence of application of fertilizers on agricultural soil. According to measured values, it can be concluded that the level of natural radioactivity in soil does not pose serious radiation risk for the human population. However, continuous and systematic monitoring is required in order to assess the level of natural radioactivity in soil.

Since corn is used as a basic raw material in the production of feed, the content of natural radionuclides in corn is also determined, and the transfer factor soil-to-corn is defined. The results indicated that radionuclide concentrations in corn are lower, and do not pose serious radiation risk for the population.

\section{REFERENCES}

[1] Tan, K. H.: Environmental Soil Sciences, University of Georgia, Athens, Georgia, 2009.

[2] Robson, M. and Toscano, W.: Risk Assessment for Environmental Health, John Wiley \& Sons, Inc., USA, 2007.

[3] Mitrović, R.: Radioaktivnost u životnoj sredini, Vrelo, Beograd, 2001.

[4] Akhtar, N., Tufail M., Asraf, M.: Natural environmental radioactivity and estimation of radiation exposure from saline soils, International Journal of Environmental Science \& Technology, 1 (4) 279-285 (2005).

[5] Mehra, R., Singh, M., Estimation of radiological risk due to concentration of ${ }^{238} \mathrm{U},{ }^{226} \mathrm{Ra},{ }^{232} \mathrm{Th}$ and ${ }^{40} \mathrm{~K}$ in soils of different geological origins in northern India, Turkish Journal of Physics, 36, 289-297 (2012).

[6] Selvasekarapandian, S., Sivakumar, R., Manikandan, N. M., Meenakshisundaram, V., Raghunath, V. M., Gajendran, V.: Natural radionuclide distribution in soils of Gudalore, India, Applied Radiation and Isotopes, 52 (2), 299306 (2000).

[7] Ademola, A. K., Bello, A. K., Adejumobi, A. C.: Determination of natural radioactivity and hazard in soil, samples in and around gold mining area in Itagunmodi, south-western Nigeria, Journal of Radiation Research and Applied Sciences, 7 (3), 249-255 (2014). 
[8] Durusoy, A., Yildirim, M.: Determination of radioactivity concentrations in soil samples and dose assessment for Rize Province, Turkey, Journal of Radiation Research and Applied Sciences, 10, 348-352 (2017).

[9] Navas, A., Soto, J., Machin, J.: ${ }^{238} \mathrm{U}$, of ${ }^{226} \mathrm{Ra},{ }^{210} \mathrm{~Pb},{ }^{232} \mathrm{Th}$, and ${ }^{40} \mathrm{~K}$ activities in soil profilas of the Flyusch Sector (Central Spanish Pyrinees), Applied Radiation and Isotopes, 57 (4), 579-589 (2002).

[10] Savci, S.: Investigation of effect of chemical fertilizers on environment, APCBEE Procedia 1, 287-292 (2012).

[11] Rezaei, F., Zadeh, H. G., Van Damme, P.: Impacts of inorganic nitrogen fertiliser on soil fertility and groundwater quality of Touba Orchards (Western Iran), Journal of Environmental Protection and Ecology, 14 (1), 71-79 (2013).

[12] Codreanu, M. D., Popa, D., Codreanu, I., Turcitu, M.: Study concerning the eco-toxicological impact of nitratesnitrites fertilisers on animal health, Journal of Environmental Protection and Ecology, 14 (1), 116-120 (2013).

[13] Mazzilli, B. P., Saueia, C. H. R., Jacomino, V. M. F., Mello, J. W. V.: Natural radionuclides and metals intake into soya, corn, and lettuce grown on soil amended with phosphogypsum, International Journal of Environmental Analytical Chemistry, 92 (14), 1574-1586 (2012).

[14] Changizi, V., Shafiei, E., Zareh, M. R.: Measurement of ${ }^{226} \mathrm{Ra},{ }^{232} \mathrm{Th},{ }^{137} \mathrm{Cs}$ and ${ }^{40} \mathrm{~K}$ activities of wheat and corn products in IIam Province - Iran, and Resultant Annual Ingestion Radiation Dose, Iranian Journal of Public Health, 42 (8), 903-914 (2013).

[15] Yordanova, I., Staneva, D., Zlatev, A., Misheva, L., Bineva, Tz., Poinarova, M.: Study of the radiocesium content in Bulgarian mushrooms for the year of 2005, Journal of Environmental Protection and Ecology, 8 (4), 934-939 (2007).

[16] Bineva, Tz., Naidenova, A., Stoeva, N.: Penetration and accumulation of $\mathrm{Cs}-137$ in beans cultivares depending on two soil types, Journal of Environmental Protection and Ecology, 2 (1), 37-41 (2001).

[17] Altekin, E., Dizman, S., Keser, R.: Radioactivity and heavy metal concentrations in various honey samples, Journal of Environmental Protection and Ecology, 16 (2), 716-722 (2015).

[18] Pulhani, V. A., Dafauti, S., Hegde, A. G., Sharma, R. M., Mishra, U. C.: Uptake and distribution of natural radioactivity in wheat plants from soil, Journal of Environmental Radioactivity, 29 (3), 33-346 (2005).
[19] Desideri, D., Meli, M. A., Roselli, C.: Natural and artificial radioactivity determination of some medicinal plants, Journal of Environmental Radioactivity, 101 (9) 751-756 (2010).

[20] Kritsananuwat, R., Kranrod, C., Chanyotha, S., Ploykrathok, T., Sriploy, P.: Natural radionuclides in agricultural plants from northern Thailand, Radiation Protection Dosimetry, 184 (3-4), 397-399 (2019).

[21] Green, N., Wilkins, B. T., Poultney, S.: Distribution of radionuclides in potato tubers: Implications for dose assessments, Journal of Radioanalytical and Nuclear Chemistry, 226, 75-78 (1997).

[22] Carvalhoa, P. F., Oliveira, J. M., Malta, M.: Radioactivity in soils and vegetables from uranium mining regions, Procedia Earth and Planetary Science, 8, 38 - 42 (2014).

[23] Manigandan, P. K.: Activity concentration of radionuclides in plants in the environment of Weatern Ghats, Iranian Journal of Radiation Research, 7 (2), 85-90 (2009).

[24] Carini, F.: Radionuclides in plants bearing fruit: an overview, Journal of Environmental Radioactivity, 46 (1), 77 97 (1999).

[25] El-Taher, A.: A study on transfer factors of radionuclides from soil to plant, Life Science Journal 10 (2), 532-539 (2013).

[26] Tome, F. V., Blanco-Rodriguez, M. P., Lozano, J. C.: Soilto-plants transfer factor for natural radionuclides and stable elements in a Mediterranean area, Journal of Environmental Radioactivity, 65 (2), 161-175 (2003).

[27] Лазаревски, А.: Климата во Македонија, Култура, Скопје 1993.

[28] Singh, S., Rani, A., Mahajan, R. K.: ${ }^{226}$ Ra, ${ }^{232} \mathrm{Th}$ and ${ }^{40} \mathrm{~K}$ in soil samples from some areas of Punjab and Himachal Pradesh, India, using gamma ray spectrometry.

[29] Iqbal, M., Tufail, M., Mirza, S. M.: Measurement of natural radioactivity in marble found in Pakistan using a $\mathrm{NaI}(\mathrm{Tl})$ gamma-ray spectrometer, Journal of Environmental Radioactivity, 51 (2), 255-265 (2000).

[30] United Nations Scientific Committee on the Effects of Atomic Radiations (UNSCEAR), Sources, effects and risks of ionizing radiation. Report of the General Assembly, United Nations, New York, 2000.

[31] https://www.iaea.org/, International Atomic Energy Agency. 